\title{
Modulation of Luteinizing Hormone(LH) Release by Clonidine and Opioid Peptides in Castrated Male Rats
}

\author{
Toshikiyo KOH, Yoshikatsu NAKAI, Fumiko KINOSHITA \\ TOSHIHIKo TSUKADA, SATORU TSUJII \\ AND HIROO IMURA
}

2nd Division, Department of Medicine

Kyoto University School of Medicine

Kyoto 606

\begin{abstract}
The effect of clonidine, a central $\alpha$-adrenergic agonist, on the suppression of LH release induced by $\beta$-endorphin or FK33-824, an endogenous opioid peptide or its synthetic analog, was investigated in castrated male rats, with or without pretreatment with reserpine. Pulsatile LH secretion was inhibited by intravenous injection of FK33-824 $(400 \mu \mathrm{g} / \mathrm{kg})$, or intraventricular injection of $\beta$-endorphin $(5 \mu \mathrm{g})$. Without pretreatment with reserpine, intraperitoneal administration of clonidine $(1 \mathrm{mg} / \mathrm{kg})$ failed to reverse the inhibition of $\mathrm{LH}$ release induced by these peptides. However, with pretreatment with reserpine $(10 \mathrm{mg} / \mathrm{kg})$, clonidine abolished the inhibitory effect on $\mathrm{LH}$ secretion induced by these peptides in castrated male rats. These data indicate that, unlike the results in ovariectomized, steroid-primed rats, pretreatment with reserpine allows the $\alpha$-adrenergic system to act more peripherally than the opioid neuronal system in a neuronal network-regulating LH release in castrated male rats.
\end{abstract}

In order to elucidate the regulatory mechanism of pulsatile $\mathrm{LH}$ release, various studies have explored the possible involvement of norepinephrine, opioid peptides and other putative neurotransmitters. Accumulataing evidence suggests that opioid peptides inhibit LH secretion (Barraclough and Sawyer, 1955 ; Pang et al., 1977; Bruni et al., 1977; Ieiri et al,. 1980), whereas norepinephrine exerts a stimulatory effect (Karla et al., 1972; Krieg and Sawer, 1976; Gallo, 1980). Opioid peptides are known to affect the

Received March 15, 1985 activities of catecholaminergic neurons of the brain (Starke et al., 1977; Meites et al., 1979). In addition to such functional interaction, histochemical studies have revealed a close anatomical interaction between norepinephrine and opioid peptides (Atweh and Kuhar, 1977; Ungerstedt, 1971). However, there are only a few reports dealing with the relationship between norepinephrine and opioid peptides in the regulation of pulsatile LH release, in which ovariectomized, steroidprimed rats are used (Karla and Simpkins, 1981; Karla and Gallo, 1983). Therefore, in order to gain further insight in modula- 
tion of $\mathrm{LH}$ release by opioid peptides and norepinephrine, we have studied the effect of clonidine on the inhibition of $\mathrm{LH}$ release induced by opioid peptides in castrated male rats.

\section{Materials and Methods}

Twenty-eight male Wistar rats, weighing 200$250 \mathrm{~g}$, were castrated and kept under conditions of controlled temperature $\left(25 \pm 1^{\circ} \mathrm{C}\right)$ and light $(12 \mathrm{~h}$ light, $12 \mathrm{~h}$ dark). Food and water were provided ad libitum. More than 4 weeks after castration, a silastic cannula was inserted through the jugular vein into the right atrium, as described previously (Kinoshita et al., 1980). A stainless steel cannula (23 gauge), was stereotaxically inserted at a point $1.5 \mathrm{~mm}$ lateral to the sagittal suture, $1 \mathrm{~mm}$ posterior to the bregma. Several days later, animals were subjected to experiments in conscious, freely moving states.

$0.5 \mathrm{ml}$ blood samples were withdrawn from the silastic cannula at $10 \mathrm{~min}$ intervals for $1 \mathrm{~h}$ before, and $2 \mathrm{~h}$ after the initial injection of $\beta$ endorphin or FK33-824. An equivalent volume of washed red cells suspended in saline was replaced after each bleeding. After centrifugation, plasma was stored at $-20^{\circ} \mathrm{C}$ until assayed.

FK33-824 ( $\left\{\mathrm{D}-\mathrm{Ala}^{2}, \mathrm{MePhe}^{4}, \operatorname{Met}(0)^{5}\right.$-ol $\}$ enkephalin, Sadoz, Basel), a potent Met $^{5}$-enkephalin analog (Roemer et al., 1977), and $\beta$-endorphin were dissolved in physiological saline at a con- centration of $4 \mathrm{mg} / 10 \mathrm{ml}$ and $5 \mu \mathrm{g} / 5 \mu \mathrm{l}$, respectively. Reserpine (Sigma Chemical Co., St. Louis, MO) was dissolved in a few drops of glacial acetic acid and diluted with $5 \%$ glucose solution to give a concentration of $1 \mathrm{mg} / \mathrm{ml}(\mathrm{pH} \mathrm{4})$. Clonidine hydrochloride (Sigma Chemical Co., St. Luis, MO), a central $\alpha$-adrenergic agonist, was dissolved in physiological saline at a concentration of $1 \mathrm{mg} / 10 \mathrm{ml}$.

The castrated rats were divided into 7 groups. The 1 st and 2 nd groups were given $\beta$-endorphin icv through the stainless steel cannula at a dose of $5 \mu \mathrm{g}$ twice at $40 \mathrm{~min}$ intervals, in combination with clonidine $(1 \mathrm{mg} / \mathrm{kg}$, ip) or saline. The $3 \mathrm{rd}$ and 4th groups received FK33-824 iv through a silastic cannula at a dose of $400 \mu \mathrm{g} / \mathrm{kg}$ twice at $40 \mathrm{~min}$ intervals, in combination with clonidine or saline. The 5th group was treated with reserpine $(10 \mathrm{mg} / \mathrm{kg}$, ip) $24 \mathrm{~h}$ before the bleedings, and injected with clonidine $(1 \mathrm{mg} / \mathrm{kg}$, ip). The 6th and 7th groups pretreated with reserpine were given clonidine in combination with FK33824 or $\beta$-endorphin.

Plasma LH concentrations were measured by double antibody radioimmunoassay using the kit provided by the National Institute of Arthritis, Metabolism and Digestive Diseases (NIAMDD), the rat Pituitary Hormone Distribution Program. As a reference standard, NIAMDD-rat-RPI was used. Intra- and inter-assay coefficients of variation were within $8 \%$ and $15 \%$, respectively. Paired or upaired $t$-test was used for analysis or the data.
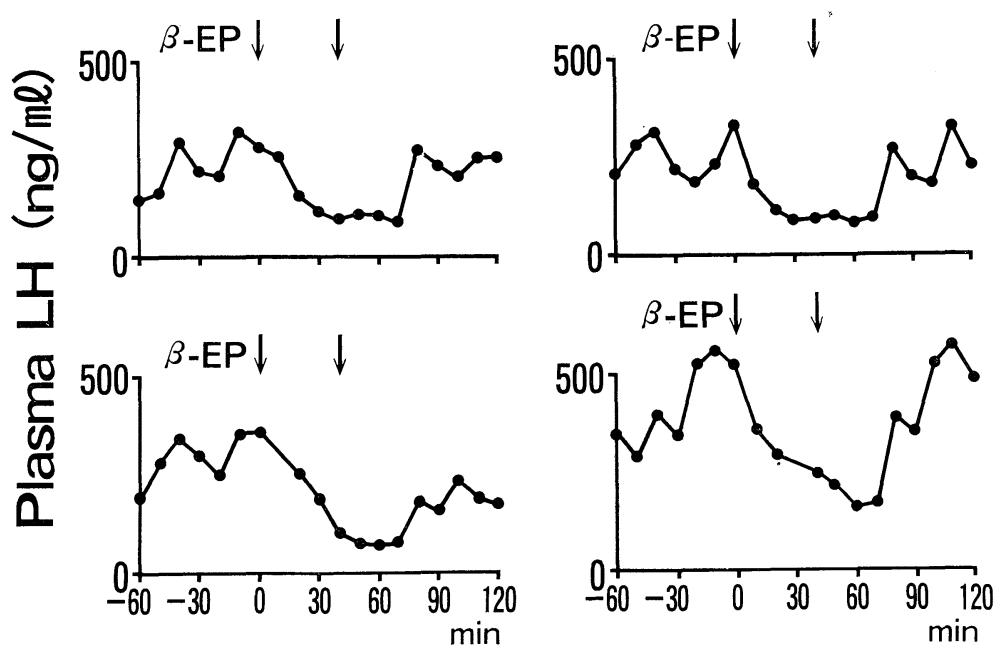

Fig. 1. Effect of repeated intracerebroventricular injections of $\beta$-endorphin ( $\beta$-EP, $5 \mu \mathrm{g}$ each time) on plasma LH levels in castrated male rats. 


\section{Results}

Figures 1 and 2 illustrate plasma LH levels before and after treatment with $\beta$ endorphin and FK33-824, respectively. All animals before the injection of $\beta$-endorphin or FK33-824 showed elevated LH release characteristic of castrated rats. Administration of $\beta$-endorphin icv or FK33-824 iv promptly lowered plasma LH levels in all animals tested. The mean plasma LH levels during the $70 \mathrm{~min}$ period after the injection of $\beta$-endorphin or FK33-824 were significantly lower than that before the injection $(\mathrm{p}<0.05)$.

Figure 3 shows the result of intraperitoneal injection of clonidine in combination with $\beta$-endorphin. The extent and duration of LH suppression were not significantly different from those induced by a combination of $\beta$-endorphin and saline (Fig. 1 vs Fig. 3). Similar results were obtained with FK33-824, as shown in Fig. 4. The extent
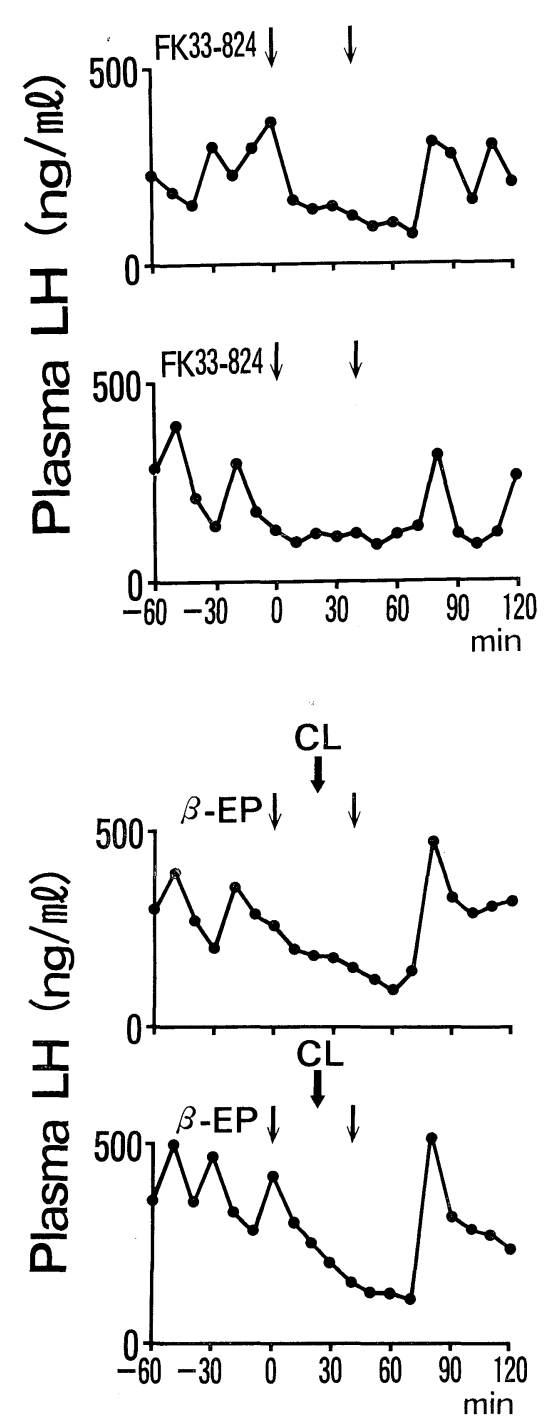
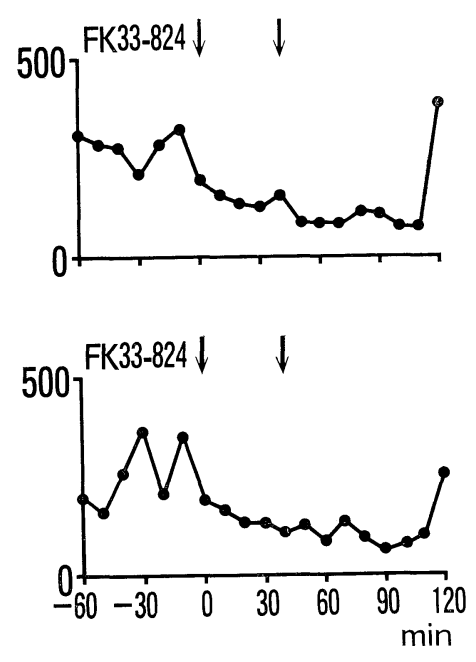

Fig. 2. Effect of repeated intravenous injections of FK 33-824 $(400 \mu \mathrm{g} / \mathrm{kg}$ each time) on plasma LH levels in castrated male rats.

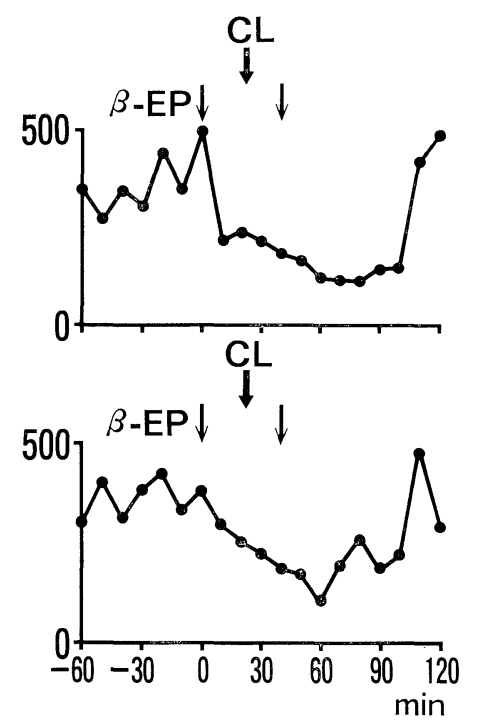

Fig. 3. Effect of intraperitoneal injection of clonidine $(\mathrm{CL}, 1 \mathrm{mg} / \mathrm{kg}$ ) on the suppression of $\mathrm{LH}$ release induced by $\beta$-endorphin $(\beta$-EP, $5 \mu \mathrm{g}$ twice). 
and duration of $\mathrm{LH}$ inhibition after the injection of FK33-824 and clonidine were almost the same as those induced by FK33824 and saline (Fig. 2 vs Fig. 4).

As shown in Fig. 5, pretreatment with reserpine suppressed elevated LH levels characteristic of castrated rats. Clonidine induced marked elevations of LH levels within $30 \mathrm{~min}$ in reserpinized rats. The peak plasma $\mathrm{LH}$ value after the clonidine injection was significantly higher than the mean preinjec- tion LH value $(p<0.05)$. In such reserpinized rats, the concurrent ip injection of clonidine with the administration of $\beta$-endorphin icv (Fig. 6) or FK33-824 iv (Fig. 7) resulted in a rise in plasma LH levels within $30 \mathrm{~min}$. Each peak plasma $\mathrm{LH}$ value was significantly higher than the mean preinjection $\mathrm{LH}$ value $(\mathrm{p}<0.05)$, and was not significantly different from that induced by clonidine alone (Fig. 6 or 7 vs Fig. 5).
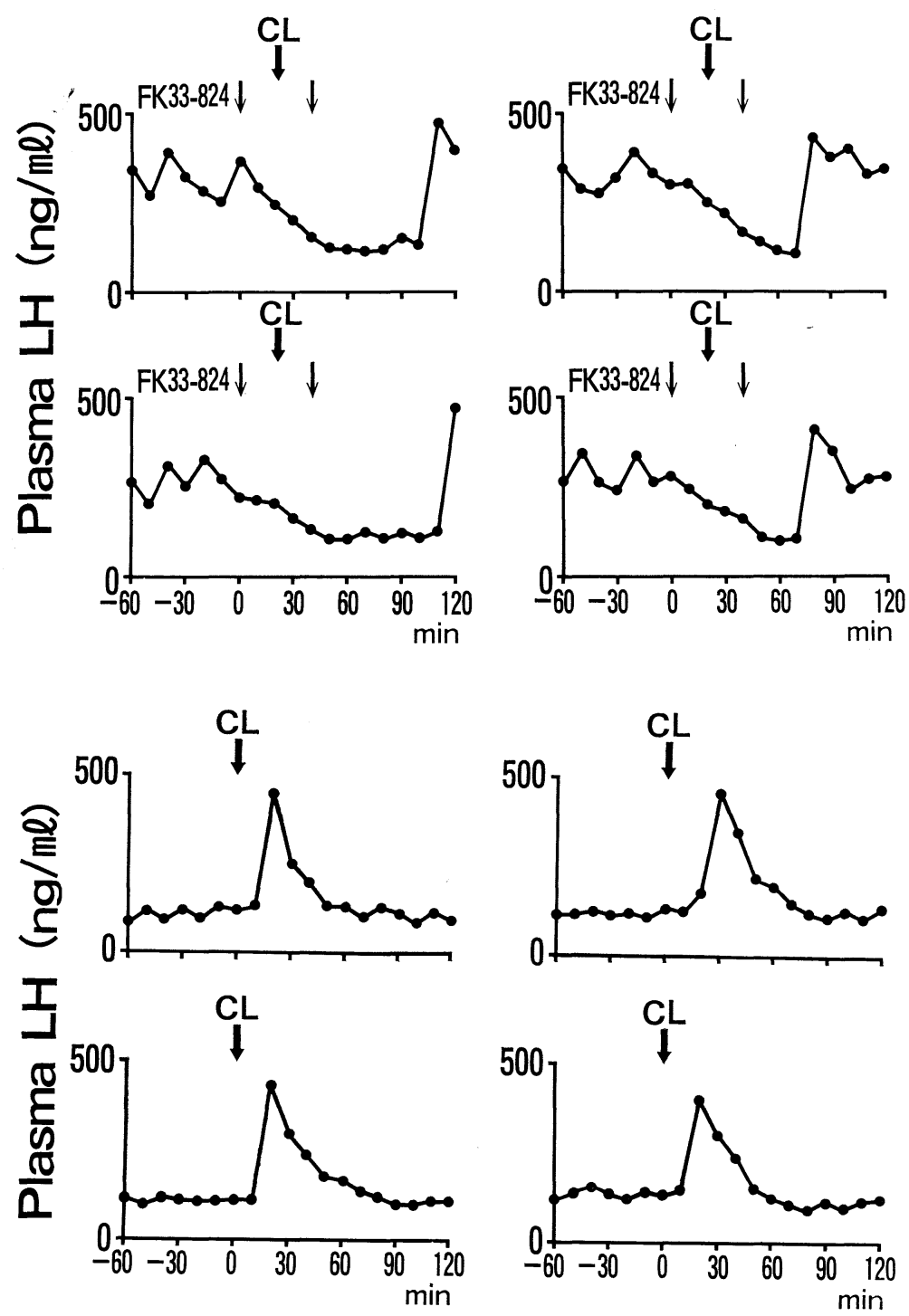
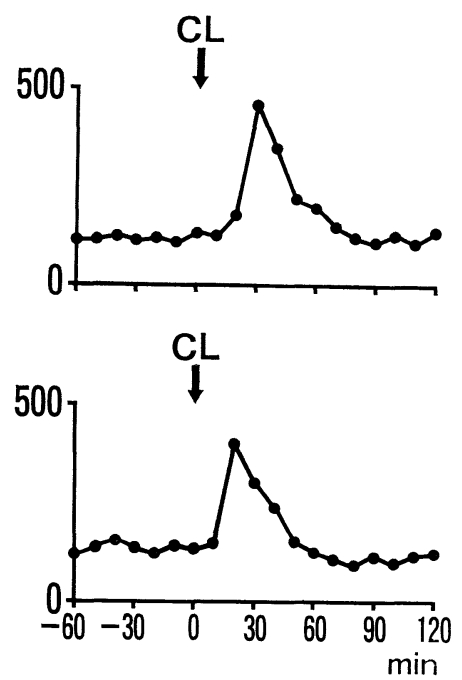

Fig. 4. Effect of intraperitoneal injection of clonidine $(\mathrm{CL}, 1 \mathrm{mg} / \mathrm{kg})$ on the suppression of LH release induced by FK-33$842(400 \mu \mathrm{g} / \mathrm{kg}$ twice $)$.
Fig. 5. Effect of intraperitoneal injection of clonidine $(\mathrm{CL}, 1 \mathrm{mg} / \mathrm{kg})$ in castrated male rats pretreated with reserpine (10 $\mathrm{mg} / \mathrm{kg}$, ip). 

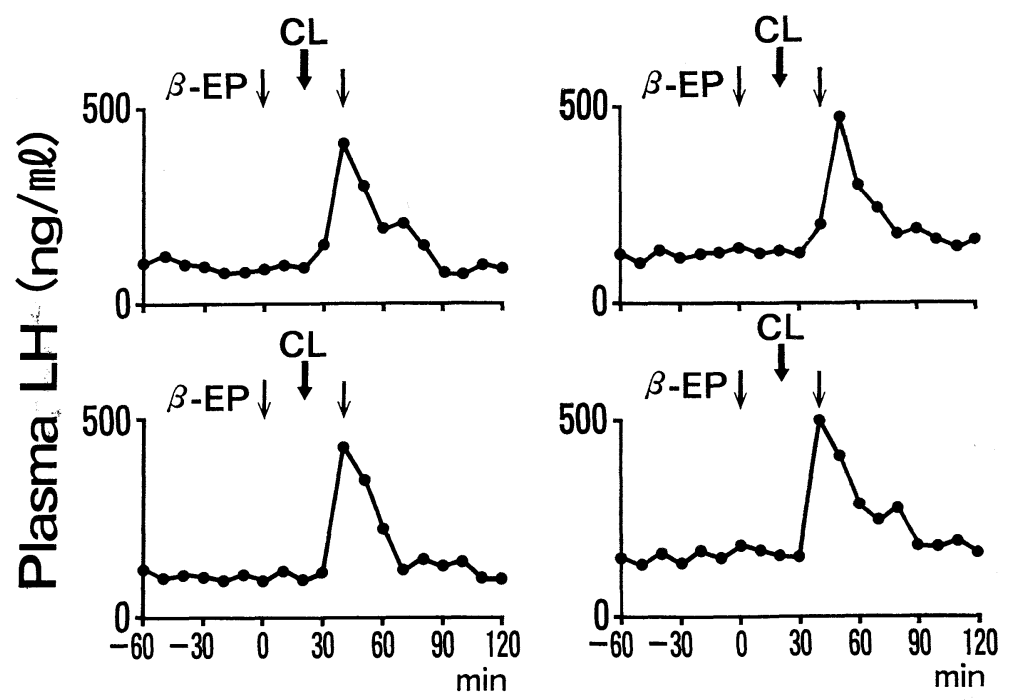

Fig. 6. Effect of the concurrent ip injection of clonidine $(\mathrm{CL}, 1 \mathrm{mg} / \mathrm{kg})$ with the icv administration of $\beta$-endorphin $(\beta$ $\mathrm{EP}, \quad 5 \mu \mathrm{g}$ twice) in castrated male rats pretreated with reserpine $(10 \mathrm{mg} / \mathrm{kg}$, ip).

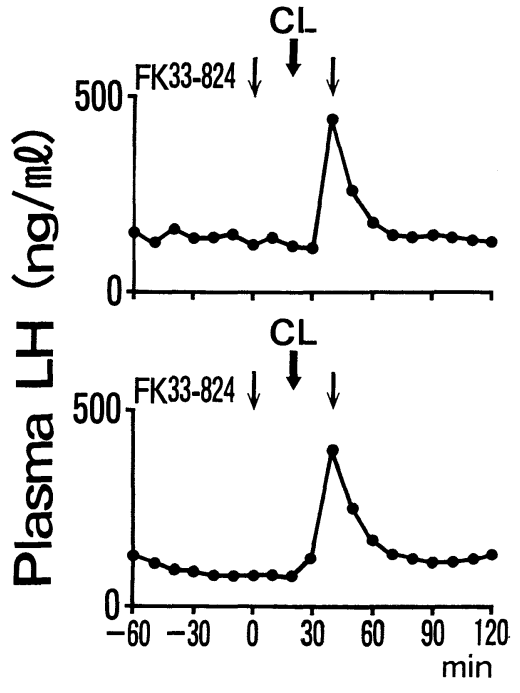

\section{Discussion}

In the present study, we show that the administration of reserpine, $\beta$-endorphin or FK33-824 suppresses episodic LH release characteristic of castrated male rats in agreement with earlier reports (Kinoshita et al., 1980; Kato et al., 1982; Kinoshita et al., 1981).
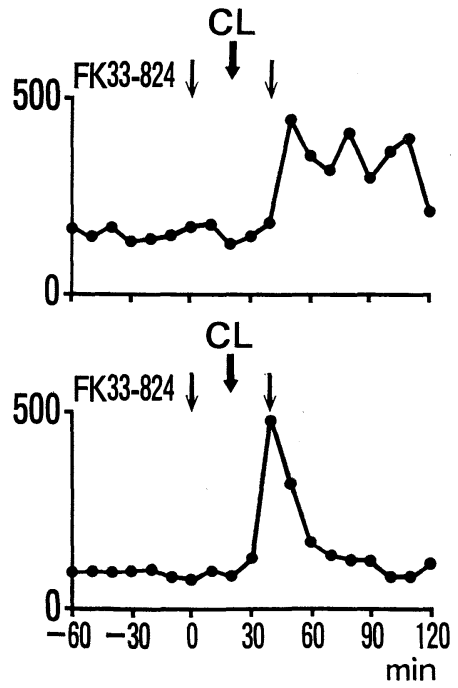

Fig. 7. Effect of the concurrent ip injection of clonidine $(\mathrm{CL}, 1 \mathrm{mg} / \mathrm{kg}$ ) with the iv administration of FK33-824 (400 $\mu \mathrm{g} / \mathrm{kg}$ twice) in castrated male rats pretreated with reserpine $(10 \mathrm{mg} / \mathrm{kg}, \mathrm{ip})$.

We find that the intraperitoneal administration of clonidine, a central $\alpha$-adrenergic agonist, fails to reverse the inhibition of $\mathrm{LH}$ release induced by opioid peptides in castrated male rats. Our results disagree with the earlier reports by Karla and Simpkins (1981), and by Karla and Gallo (1983); the former states that clonidine ip raises plasma LH levels in morphine-treated, ovariectomized, estrogen-progesterone-primed rats, and 
latter that intraventricular infusion of norepinephirine radily elicits well defined episodoes of LH hypersecretion in morphinetreated, ovariectomized, estrogen-progesterone-primed rats. A possible explanation for the discrepancy between their results and ours is that our experimental design is different from theirs. It could be speculated that the relationship between norepinephrine and opioid peptides in the regulation of pulsatile $\mathrm{LH}$ release in castrated male rats is different from that in ovariectomized, estrogen-progesterone-primed rats.

We also observe that clonidine abolishes the inhibitory effect of opioid peptides on LH secretion in castrated male rats pretreated with reserpine. Such an apparently discordant action of clonidine on $\mathrm{LH}$ release, although depending on the pretreatment with reserpine, is difficult to comprehend. It is known that clonidine can stimulate both postsynaptic $\alpha_{1}$-receptor and presynaptic $\alpha_{2}$-receptor, and that activation of $\alpha_{2}$-receptor results in a decrease in the amount of norepinephrine released and a reduction in the firing rate of noradrenergic neurons (Svensson et al., 1975). Moreover it is also reported that the affinity of clonidine for $\alpha_{1}$ receptor is much weaker than its affinity for $\alpha_{2}$-receptor (Haga and Haga, 1980). Therefore, one explanation is that pretreatment with reserpine, which can deplete brain norepinephrine levels, might diminish the inhibitory effect mediated via presynaptic $\alpha_{2}$-receptor, thus promoting the action of clonidine on postsynaptic $\alpha_{1}$-receptor and resuling in the stimulation of $\mathrm{LH}$ release. At the same time, without pretreatment with reserpine, clonidine can acativate $\alpha_{2}$-receptor, thus resulting in an autofeedback regulation of norepinephrine and a failure to stimulate $\mathrm{LH}$ release.

However, in the brain, reserpine is also able to deplete dopamine and 5-hydroxytryptamine which are known to suppress pulsatile LH release (Drouva and Gallo, 1977; Gallo and Moberg, 1977). Another explanation is that without pretreatment with reserpine, the administration of clonidine could activate the noradrenergic, dopaminergic and serotoninergic neuronal system, and fail to stimulate $\mathrm{LH}$ secretion.

In summary, unlike results in ovariectomized, steroid-primed rats, pretreatment with reserpine may allow the $\alpha$-adrenergic system to act more peripherally than the opioid neuronal system in a neuronal network regulating LH release in castrated male rats.

\section{Acknowledgements}

We thank Sandoz Pharmaceuticals for the provision of FK33-824, the Hormone Distribution Program of the NIAMDD National Pituitary Agency for the supply of the materials used in the RIA, and Miss Y. Mitsuda, Miss J. Takayama and Miss N. Yamamoto for assistance with the manuscript.

\section{References}

Atweh, S. F. and M. J. Kuhar (1977). Autoradiographic localization of opiate receptors in rat brain. II. The brain stem. Brain Res. 129, 1-12.

Barraclough, C. A. and C. H. Sawyer (1955). Inhibition of the release of pituitary hormone in the rat by morphine. Endocrinology 57, 329-337.

Bruni, J. J., D. A. Van Vugt and S. Marshall (1977). Effect of naloxone, morphine and methionine enkephalin on serum prolactin, luteinizing hormone, follicle stimulating hormone, thyroid stimulating hormone and growth hormone. Life Sci. 21, 461-466.

Drouva, S. V. and R. V. Gallo (1977). Further evidence for inhibition of episodic luteinizing hormone release in ovariectomized rats by stimulation of dopamine receptors. Endocrinology 100, 792-798.

Gallo, R. V. and G. Moberg (1977). Serotoninmediated inhibition of episodic luteinizing hormone release during electrical stimulation of the arcuate nucleus in ovariectomized rats. Endocrinology 100, 945-954.

Haga, T. and D. Haga (1980). Characterization 
of alpha-adrenergic receptor subtypes. Life Sci. 26, 211-218.

Ieiri, T., H. T. Chen, G. A. Campbell and J. Meites (1980). Effects of naloxone and morphine on the proestrous surge of prolactin and gonadotropins in the rat. Endocrinology 106, 1568-1570.

Karla, P. S., S. P. Karla, L. Krulich, C. P. Fawcett and S. M. McCann (1972). Involvement of norepinephrine in transmission of the stimulatory influence of progesterone on gonadotropin release. Endocrinology 90, 1168-1176.

Karla, S. P. and J. W. Simpkins (1981). Evidence of noradrenergic mediation of opioid effects on luteinzing hormone release in morphine-treated rats. Endocrinology 109, 776-782.

Karla, S. P. and R. V. Gallo (1983). Effect of intraventricular administration of catecholamines on luteininzing hormone release in morphinetreated rats. Endocrinology 113, 23-28.

Kato, Y., S. Hiroto, H. Katakami, N. Matsushita, A. Shimatsu and H. Imura (1982). Effects of a synthetic Met $^{5}$-enkephalin analog on plasma luteinizing hormone and prolactin levels in conscious orchiectomized rats. Proc. Soc. Exp. Biol. Med. 169, 95-100.

Kinoshita, F., Y. Nakai, H. Katakami, Y. Kato, H. Yajima and H. Imura (1980). Effect of $\beta$-endorphin on pulsatile luteinizing hormone release in conscious castrated rats. Life Sci. 27, 853-846.

Kinoshita, F., Y. Nakai, H. Katakami, Y. Kato and H. Imura (1981). Role of $\alpha$-adrenergic mechanism in regulating tonic luteinizing hormone release in conscious ovariectomized rats. Endocrinology 108, 1272-1275.

Krieg, R. J. and C. H. Sawyer (1976). Effects of intraventricular catecholamines on luteinizing hormone release in ovariectomized steroidprimed rats. Endocrinology 99, 411-419.

Meites, J., J. F. Bruni, D. A. Van Vugt and A. F. Smith (1979). Relation of endogenous opioid peptides and morphine to neuroendocrine function. Life Sci. 24, 1325-1336.

Pang, C. N., E. Zimmermnn and C. H. Sawyer (1977). Morphine inhibition of the preovulatory surges of plasma luteinizing hormone and follicle stimulating hormone in the rat. Endocrinology 101, 1726-1732.

Roemer, D., H. H. Buescher, R. C. Hill, J. Press, W. Bauer, F. Cardinaux, A. Closse, D. Hauser and R. Huguenin (1977). A synthetic enkephalin analogue with prolonged parenteral and oral analgesic activity. Nature (London) 268, 547-549.

Starke, K., H. D. Taube and E. Borowski (1977). Presynaptic receptor system in catecholaminergic transmission. Biochem. Pharmacol. 26, 259-268.

Svensson, T. H., B. S. Bunney and G. K. Aghajanian (1975). Inhibition of both NA and 5-HT neurons in brain by the alpha agonist clonidine. Brain Res. 92, 291-306.

Ungerstedt, W. (1971). Stereotaxic mapping of monoamine pathways in the rat brain. Acta Physiol. Scand. (Suppl.) 367, 1-48. 